\title{
EFL Learners' Learning Styles and Their Attributes
}

\author{
Yuliya Viktorovna Razvadovskaya \\ Inna Konstantinovna Shevchenko \\ Marina Aleksandrovna Grezina
}

Southern Federal University 05/42 Bolshaya Sadovaya Str., Rostov-on-Don, 344006, Russia

Email: yuliyaraz@yandex.ru

\section{Doi:10.5901/mjss.2015.v6n3s4p253}

\section{Abstract}

The influence of branch concentration, the state support, a direct foreign investments and abilities to training, on enterprises borrowing and generating new technologies in the branches of information and telecommunication technologies is analyzing in the articles. The analysis of these factors importance for enterprises using various innovative strategies has been carried out by means of Pearson's correlation factors. On results of the analysis it has been revealed that the main shares of the enterprises in branch are using the strategy of borrowing new technologies. Thus the major factors influencing the enterprises, using this strategy, are: the concentration of branches, volume of direct foreign investments and the state support. The technological progress lies on the bases of economic development. But the innovative processes being the basis of technological progress have various characteristics in advanced and developing countries. In developing countries of the innovations are generally created at the expense of absorption and adaptation of technologies developed in the other countries. The development process of absolutely new technologies in developing countries has a very weak intensity. The strategy of innovative development directed on innovations production, inclusive an engineering and creation of new technologies is applied on a large scale in advanced countries. In developing countries it is applied the strategy of innovations borrowing.

Keywords: the enterprise innovative strategy, dynamic abilities, direct foreign investments, state support, hi-tech sector, ICT.;

\section{Introduction}

Despite of importance of innovative activity for technological progress the majority of existing researches accept for strategy of borrowing and manufacturing of new technologies as reality, without analyzing, why the advanced countries buy the technologies, instead of generating. Absence of such researches in Russia has defined the tasks of this article which results can become important for state policy of regulation of innovative development of high-technology industries Shevchenko, Razvadovskaya (2013).

In many researches it is noted that the knowledge base, structure of the market and technology influence on innovations Malerbra Fagerberg, (2008); Srholec, (2003). Thus only some researches analyze the influence of foreign competitiveness, structure of external and internal investments into enterprises using a various innovative strategy. In nowadays it is observed the lack of researches which analyze an influence of such factors as the competitiveness and investments on activity connected to production and borrowing the new technologies of the hi-tech enterprises in developing countries Cantner, Pyka, (2001) Malerba, (1997).

Unlike the previous researches considering the results of separate firms' activity, in this article the data is considered at branches level that makes available identification of branch innovative development determinant. The results received during analysis of separate firms are difficult to apply for branch or industry, thus the analysis results of one branch can be employed for some other branches of hi-tech sector. Hence, the results of research allow looking at innovative development of domestic enterprises of hi-tech sector in a new way. The researches results are actual for Russian economy which is aiming to realize the structural shears in the industry and to pass to high-technology economy industries development. The received results can be applicable for many developing countries, in particular, for other countries of BRIK group occupied on formation of innovative system. 


\section{Theory and Hypotheses}

By the present moment there were some actual directions of research of connection existing between the innovations and industry growth in developing countries. It is macro - and microeconomic directions in which is noted that the development of innovative system can occur in two ways. The first way assumes the international transfer of technologies. I.e. an application of strategy of new technologies being borrowed at the expense of technologies exporting through the direct foreign investments and transnational corporations Shevchenko, Razvadovskaya (2014). The effects from new technologies and the scale of their distribution can be unequal in different countries. It depends on ability of the countries effectively to absorb the new technologies Lall, (1992) Park, (1999). Hence, the level of innovative development depends not just on access to new technologies, but also from absorbing abilities of the country Cohen, Levinthal, (1989). In the report of the World Bank it is said that the absorbing possibilities of the country depend on many factors, including the literacy level of engineering staff, investment climate and institutional structure as well.

Thus, in this article an attempt is undertaken in order to reveal the dependence between the concentration, foreign competition, level of knowledge, state support and strategy of innovative development in ICT branch. On the analysis of theoretical provisions on this perspective it is formed the hypotheses which equity will be established by means of analysis of empirical material and modeling.

\subsection{Concentration of the branch.}

Concentration of branch plays an important role in definition of enterprise strategy. According to theory of industrial organization the branch structure creates a behavior of the firms that in turn defines the branch productivity Scherer, Ross (1990). The support of this thesis is provided also by other researches Donsimoni, Geroski, Jacquemin (1990); Belman, Heywood (1984). Analyzing the literature concerning the organizational efficiency in the branch it is possible to draw the conclusion that the competitive pressure in the branch leads to more effective work of the enterprises. The high competition stimulates the development of innovations, professional improvement and development of new administrative solutions in the branch. At low concentration of the branch the effective distribution of resources [weakens. According to hypothesis about X-efficiency the absence of competition raises inefficiency of production and drives to increase in expenses Lawrence, Lorsch (1967).

Hypothesis 1. High concentration in the branch will strongly influence the enterprises buying and creating the technologies.

\subsection{Direct foreign investments.}

The direct foreign investments promote an economic growth in host countries directly and indirectly. They assist an employment, increase of competences, and also a creation of new technologies in the host country. FDI represent the most important and cheapest source of direct technologies transfer to developing countries Buisseret, Cameron, Georghiou, (1995).

Hypothesis 2. FDI will influence more strongly on enterprises which are using the strategy of borrowing the new technologies.

\subsection{Dynamic abilities to training.}

In many researches it was discovered an inverse relationship between the quality of the human capital and activities on new technologies production. At these researches it was proved an importance of knowledge modulation, as the mechanism for promoting the innovations creation Brown, Duguid, (1991); Jaffe, Trajtenberg, (1993). The intensity of workers qualification is one of the main characteristics of the knowledge base in the branch Malerba, Orsenigo, (2000). The qualification of workers is the characteristic of their skills and encloses the contribution to creation of new technology cost. Extension of the knowledge base renders a direct impact on the enterprises taken with development of new technologies.

Hypothesis3. A high level of ability to training positively influences on enterprises making new technologies.

\subsection{State support.}

The main priority with support of branch is presented the importance in technological progress Fonotov (2013) Djankov, 
Hoekman, (2000). In connection to this argument the main objects of the state subsidies in Russia are the hightechnology industries, including ICT. Due to that the state intervention into innovative policy is connected with own innovative potential development, the main part of the state investments will be concentrated in the domestic enterprises occupied with development of new technologies. Such subsidies shall influence positively on upswing of research works activity in organizations occupied with new technologies engineering.

Hypothesis5. The state investments exert an influence more strongly on enterprises which are using the strategy of new technologies productions.

\section{Data and Methodology}

In this research the panels of Russian statistical data compendium utilize since 2005 till 2012 on the branch of information and telecommunication technologies are used. The value of the given branch in innovative development of Russian economy is difficult for overestimating Ganichev (2013). For calculation of indicators the data of statistical year-books «Information oriented society», «Indicators of innovative activity», "Industry" were used. As the analysis unit in this research the branch acts. All enterprises of branch are divided into the enterprises buying technologies (borrowing strategy) and the enterprises creating technologies. For analysis of influence of industry architecture on the enterprises manufacturing and buying technologies the dependent and independent variables are used.

The technologies production: the ratio of expenses on development of new technologies and products to total number of firms in the branch. The higher in the branch the share of firms manufacturing the new technologies, the higher own innovative potential and the closer is branch to technological border Hoekman, Maskus, Saggi, (2005).

The technologies borrowing: the ratio of expenses on purchasing the new technologies and products to the total number of firms into the branch.

\subsection{The variables dependent}

The direct foreign investments: the ratio of direct foreign investments volume to the total amount of investments into the branch.

Internal abilities to training: the ratio of workers number with the highest level of qualification to the total number of workers in the branch. The higher the indicator the higher the intensity speed of training dynamic aptitudes.

The state support: the ratio of the state investments to the total amount of investments into the branch.

Concentration of the branch: the ratio of the volume of the branch enterprises release to the total number of enterprises in the branch. The higher the indicator the higher a concentration in the branch and the more intensive the internal competition is. branch.

Outsourcing: the ratio of expenses on off-site organizations services to the total amount of expenses on ICT in the

The outlays of Russian organizations on training of employees connected to utilization of ICT: the ratio of outlays of Russian organizations on employees training connected to ICT to the total number of outlays in the branch.

\subsection{The technology of analysis}

For analysis of industry architecture influence on the enterprises borrowing and manufacturing the new technologies have been worked out the estimated equations:

Borrowing the technologies $=$ (borrowing firms $)+($ volume of production $)+($ year $)+($ FDI + internal knowledge + the state investments $)+($ concentration + abilities to training + outsourcing $)+$ mistake

Production of technologies $=$ (manufacturing firms $)+($ volume of production $)+($ year $)+($ FDI + internal knowledge + the state investments) + (concentration + outsourcing + abilities to training $)+$ mistake

The equations involve with the variable and constant factors. The system of the equations contains unknown parameters. Therefore the assessment of the equations occurs with the help of the method of smallest squares. The equations involve with indicators of the enterprises borrowing and manufacturing the new technologies that allows considering them as mutually dependent.

\section{Empirical Analysis}

For carrying out the correlation and regression analysis in research it is used the package of the statistical programs 
SPSS 11.0.

The greatest interest represent causal-investigatory relations between the phenomena of the innovative sphere of the state development that allows to reveal the factors, making the greatest impact on process of production and borrowing the new technologies. For calculation of parameters $a_{0}, a_{1}, a_{2}, \ldots, a_{n}$ numerical values it was used the previously cumulative massif of observations for the period since 2005 till year 2011. The results of analysis are provided in table 1.

Regression analysis results (tab. 1) have not revealed an extent of exogenous factors influence on endogenous factors that accounts for by the low number of presented surveillance file on studied process and considered factors joint development.

On the first step of the factorial analysis procedure in the research there is standardization of variables preset values (z-transformation) takes place that allows to solve an objective of data normalizing; then by means of standardized values the calculation of correlation Pearson factors between the considered variables has been carried out. Initial element for further calculations was the correlation matrix. For which construction it was defined, so-called, own values and complying to them own vectors of matrix diagonal elements.

Table 1. The results of correlative and regressive analyses

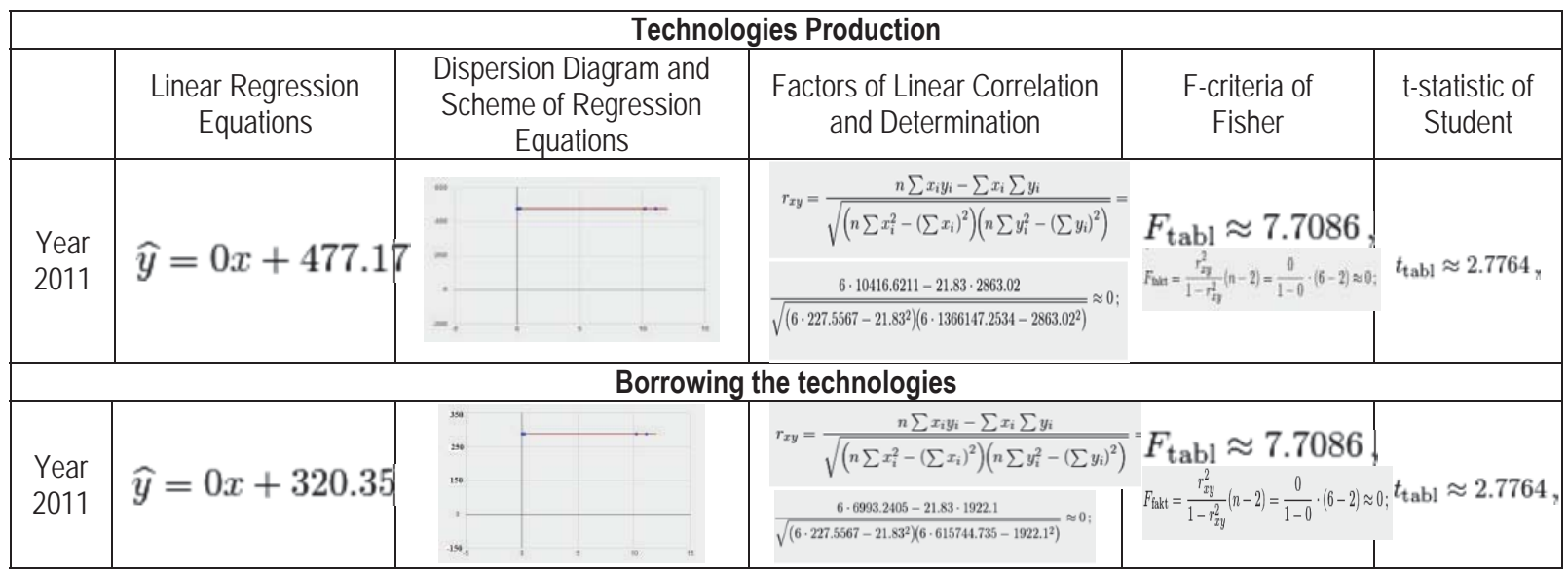

The factorial analysis was carried out for identification of degree of variables dependence on development of the enterprises buying or creating the technologies. As a result of carried-out factorial analysis, 6 factors (see table 2) have been selected.

From table 2 it is visible that there 6 own values are surpassing the unit that means the selection of six factors is done. The first factor explains $32,475 \%$ of the summary dispersion, the second factor of $13,569 \%$, the third $-11,221 \%$, the fourth factor $-5,833 \%$, the fifth factor $-4,882 \%$ and the sixth factor $-3,861 \%$.

Table 2. The explained cumulative dispersion(production of technologies and technologies borrowing)

\begin{tabular}{|c|c|c|c|c|c|}
\hline \multirow[b]{2}{*}{ Component } & \multicolumn{3}{|c|}{ Initial own values } & \multicolumn{2}{|c|}{ Rotated summary of loading square } \\
\hline & Sum & $\%$ dispersion & & Sum & $\%$ dispersion \\
\hline 1 & 10,21 & 32,475 & 32,475 & 12,340 & 32,475 \\
\hline 2 & 9,07 & 13,569 & 46,043 & 5,156 & 13,569 \\
\hline 3 & 8,264 & 11,221 & 57,264 & 4,264 & 11,221 \\
\hline 4 & 6,217 & 5,833 & 63,097 & 2,217 & 5,833 \\
\hline 5 & 4,855 & 4,882 & 67,980 & 1,890 & 4,882 \\
\hline 6 & 1,467 & 3,861 & 71,840 & 1,007 & 3,861 \\
\hline
\end{tabular}

Selection method: The main components analyses.

To explain the selected factors the turned matrix (tab. 3,4) allows. On matrix diagonal in block view the factorial loadings of six factors are located. The variables are inside of one block, are sorted in decreasing order of factorial loadings. As it has already been noted, the factorial loadings should be understood as the correlation coefficients between the variables and factors. 
Table 3. Results of the factorial analysis (production of technologies)

\begin{tabular}{|c|c|c|c|c|c|c|c|c|}
\hline \multirow[t]{2}{*}{ Variables name } & \multicolumn{2}{|c|}{ Indicators for calculation } & \multicolumn{6}{|c|}{ Factor } \\
\hline & & & 1 & 2 & 3 & 4 & 5 & 6 \\
\hline \multirow[t]{7}{*}{ Concentration of the branch } & $2005-6,06$ & 85,85 & 0,704 &,$"$, &,$"$ & "," &,$"$, &,$"$ \\
\hline & $2006-6,95$ & 83,40 & & & & & & \\
\hline & $2007-6,12$ & 74,36 & & & & & & \\
\hline & $2008-8,24$ & 72,40 & & & & & & \\
\hline & $2009-10,02$ & 69,84 & & & & & & \\
\hline & $2010-9,87$ & 170,09 & & & & & & \\
\hline & $2011-10,21$ & 477,17 & & & & & & \\
\hline \multirow{7}{*}{$\begin{array}{l}\text { Russian organizations outlays on personnel training } \\
\text { connected to use of ICT }\end{array}$} & $2005-0,01$ & 85,85 &,, & 0,681 &,$"$, &,$"$ &,$"$, &,$"$, \\
\hline & $2006-0,01$ & 83,40 & & & & & & \\
\hline & $2007-0,01$ & 74,36 & & & & & & \\
\hline & $2008-0,01$ & 72,40 & & & & & & \\
\hline & $2009-0,01$ & 69,84 & & & & & & \\
\hline & $2010-0,01$ & 170,09 & & & & & & \\
\hline & $2011-0,01$ & 477,17 & & & & & & \\
\hline \multirow[t]{7}{*}{ The state support } & $2005-0,1$ & 85,85 & ,", &,$"$, & 0,532 & ,", & "," & ,", \\
\hline & $2006-0,1$ & 83,40 & & & & & & \\
\hline & $2007-0,06$ & 74,36 & & & & & & \\
\hline & $2008-0,09$ & 72,40 & & & & & & \\
\hline & $2009-0,11$ & 69,84 & & & & & & \\
\hline & $2010-0,11$ & 170,09 & & & & & & \\
\hline & $2011-0,24$ & 477,17 & & & & & & \\
\hline \multirow[t]{7}{*}{ Direct foreign investments } & $2005-0,02$ & 85,85 &,$"$ &,$"$, & ,", & 0,428 & ", & ", \\
\hline & $2006-0,02$ & 83,40 & & & & & & \\
\hline & $2007-0,02$ & 74,36 & & & & & & \\
\hline & $2008-0,04$ & 72,40 & & & & & & \\
\hline & $2009-0,08$ & 69,84 & & & & & & \\
\hline & $2010-0,07$ & 170,09 & & & & & & \\
\hline & $2011-0,07$ & 477,17 & & & & & & \\
\hline \multirow[t]{7}{*}{ Outsorting } & $2005-0,16$ & 85,85 &,$"$ & ,", &,$"$ &,$"$, & 0,386 & ,", \\
\hline & $2006-0,17$ & 83,40 & & & & & & \\
\hline & $2007-0,19$ & 74,36 & & & & & & \\
\hline & $2008-0,18$ & 72,40 & & & & & & \\
\hline & $2009-0,19$ & $2009-69,84$ & & & & & & \\
\hline & $2010-0,19$ & 170,09 & & & & & & \\
\hline & $2011-0,2$ & 477,17 & & & & & & \\
\hline \multirow[t]{7}{*}{ Aptitudes for training } & $2005-7,5$ & 85,85 &,$"$, & ,", & ,", &,$"$, &,$"$, & 0,356 \\
\hline & $2006-6,8$ & 83,40 & & & & & & \\
\hline & $2007-6,4$ & 74,36 & & & & & & \\
\hline & $2008-6,8$ & 72,40 & & & & & & \\
\hline & $2009-10,1$ & 69,84 & & & & & & \\
\hline & $2010-10,7$ & 170,09 & & & & & & \\
\hline & $2011-11,1$ & 477,17 & & & & & & \\
\hline
\end{tabular}

Table 4. The results of factor analyses (borrowing of technologies)

\begin{tabular}{|c|c|c|c|c|c|c|c|c|c|}
\hline \multirow[t]{2}{*}{ Coefficient name } & \multicolumn{3}{|c|}{ Indicators for calculation } & \multicolumn{6}{|c|}{ Factor } \\
\hline & & & & 1 & 2 & 3 & 4 & 5 & 6 \\
\hline \multirow[t]{7}{*}{ Branch concentration } & $2005-6,06$ & 133,92 & & 0,985 &,, &,$"$, & ,", &, &,$"$, \\
\hline & $2006-6,95$ & 127,10 & & & & & & & \\
\hline & $2007-6,12$ & 132,20 & & & & & & & \\
\hline & $2008-8,24$ & 141,80 & & & & & & & \\
\hline & $2009-10,02$ & 175,88 & & & & & & & \\
\hline & $2010-9,87$ & 166,76 & & & & & & & \\
\hline & $2011-10,21$ & 320,35 & & & & & & & \\
\hline \multirow[t]{2}{*}{ Direct foreign investments } & $2005-0,02$ & 133,92 & 85,85 &,$"$, & ,", &,$"$, & 0,758 &,$"$, &, \\
\hline & $2006-0,02$ & 127,10 & 40,5 & & & & & & \\
\hline
\end{tabular}




\begin{tabular}{|c|c|c|c|c|c|c|c|c|c|}
\hline & $2007-0,02$ & 132,20 & 74,36 & & & & & & \\
\hline & $2008-0,04$ & 141,80 & 72,40 & & & & & & \\
\hline & $2009-0,08$ & 175,88 & 69,84 & & & & & & \\
\hline & $2010-0,07$ & 166,76 & 170,09 & & & & & & \\
\hline & $2011-0,07$ & 320,35 & 477,17 & & & & & & \\
\hline \multirow[t]{7}{*}{ The state support } & $2005-0,1$ & 133,92 & 85,85 & \multirow{7}{*}{ "', } & \multirow{7}{*}{ ", } & \multirow[t]{7}{*}{0,633} & \multirow[t]{7}{*}{ ", } & \multirow{7}{*}{$"}$, & \multirow{7}{*}{ "', } \\
\hline & $2006-0,1$ & 127,10 & 83,40 & & & & & & \\
\hline & $2007-0,06$ & 132,20 & 74,36 & & & & & & \\
\hline & $2008-0,09$ & 141,80 & 72,40 & & & & & & \\
\hline & $2009-0,11$ & 175,88 & 69,84 & & & & & & \\
\hline & $2010-0,11$ & 166,76 & 170,09 & & & & & & \\
\hline & $2011-0,24$ & 320,35 & 477,17 & & & & & & \\
\hline \multirow{7}{*}{$\begin{array}{l}\text { Outlays of Russian organizations on } \\
\text { training of personnel connected with use } \\
\text { of ICT }\end{array}$} & $2005-0,01$ & 133,92 & 85,85 & \multirow[t]{7}{*}{ "', } & \multirow[t]{7}{*}{0,495} & \multirow[t]{7}{*}{ ", } & \multirow[t]{7}{*}{ "', } & \multirow[t]{7}{*}{ "," } & \multirow[t]{7}{*}{$"}$, \\
\hline & $2006-0,01$ & 127,10 & 83,40 & & & & & & \\
\hline & $2007-0,01$ & 132,20 & 74,36 & & & & & & \\
\hline & $2008-0,01$ & 141,80 & 72,40 & & & & & & \\
\hline & $2009-0,01$ & 175,88 & 69,84 & & & & & & \\
\hline & $2010-0,01$ & 166,76 & 170,09 & & & & & & \\
\hline & $2011-0,01$ & 320,35 & 477,17 & & & & & & \\
\hline \multirow[t]{7}{*}{ Aptitudes for training } & $2005-7,5$ & 133,92 & 85,85 & \multirow[t]{7}{*}{$"}$, & \multirow[t]{7}{*}{ ", } & \multirow[t]{7}{*}{,$"}$, & \multirow[t]{7}{*}{ ", } & \multirow[t]{7}{*}{$"}$, & \multirow[t]{7}{*}{0,456} \\
\hline & $2006-6,8$ & 127,10 & 83,40 & & & & & & \\
\hline & $2007-6,4$ & 132,20 & 74,36 & & & & & & \\
\hline & $2008-6,8$ & 141,80 & 72,40 & & & & & & \\
\hline & $2009-10,1$ & 175,88 & 69,84 & & & & & & \\
\hline & $2010-10,7$ & 166,76 & 170,09 & & & & & & \\
\hline & $2011-11,1$ & 320,35 & 477,17 & & & & & & \\
\hline \multirow[t]{7}{*}{ Outsorting } & $2005-0,16$ & 133,92 & 85,85 & \multirow[t]{7}{*}{$" \prime$} & \multirow[t]{7}{*}{ '"' } & \multirow[t]{7}{*}{ "'" } & \multirow{7}{*}{ "'" } & \multirow[t]{7}{*}{0,386} & \multirow{7}{*}{ "', } \\
\hline & $2006-0,17$ & 127,10 & 83,40 & & & & & & \\
\hline & $2007-0,19$ & 132,20 & 74,36 & & & & & & \\
\hline & $2008-0,18$ & 141,80 & 72,40 & & & & & & \\
\hline & $2009-0,19$ & 175,88 & 69,84 & & & & & & \\
\hline & $2010-0,19$ & 166,76 & 170,09 & & & & & & \\
\hline & $2011-0,2$ & 320,35 & 477,17 & & & & & & \\
\hline
\end{tabular}

\section{The Results of the Analysis}

The results of analysis testify that such factors as concentration of branch, direct foreign investments, the state support, outlays for training of employees and outsourcing with different degree influence ton he enterprises productions using the strategy and borrowing strategy.

Such indicator as concentration of branch more influences on the enterprises which use the strategy of technologies borrowing and is equal 0,985 , besides that for the enterprises using the production strategy this indicator is equal 0,704 .

The second on its importance factor, for enterprises using the strategy of new technologies production are the costs of the Russian organizations on employees training connected with ICT. For this group of companies the indicator is equal 0,681, and for the enterprises using the borrowing strategy - 0,495.

On the third place on importance of influence on activity of the enterprises manufacturing new technologies there is the state support which is considered as the state investments. This indicator is equal 0,532 for the enterprises manufacturing new technologies and 0,633 for the enterprises using the borrowing strategy.

The received results disprove the hypothesis that the state support will influence in more extent onto enterprises employing the strategy of new technologies productions. The results of the analysis testify that the state support exert strong influence on both groups of entities, with little deviation in favor of the enterprises borrowing the new technologies. This tendency can be connected with that the public financing is used by enterprises for purchasing the new technologies in the countries advanced. That also is a positive tendency at stage of technological base accumulation, the knowledge base in the conditions of developing economy.

The least value has such factors as an outsourcing and the aptitudes to training which values are equal 0,386 and 0,356 for the enterprises using the strategy of new technologies production. The importance of these factors is not essential, nevertheless, the abilities to training are very significant indicator of the enterprises of high-technology 
industries.

\section{Conclusions and Restrictions}

On the basis of these statistical data on ICT branch, in this article it is given a try to analyze the processes in the field of technological development in developing countries by assessment of influence of internal and external factors onto enterprises have chosen the strategy of borrowing and manufacturing the new technologies.

From our point of view the orientation on the Russian economy allows to analyze the development of hightechnology industry in the country with emerging market of hi-tech goods. The heritage of the isolated economy and protectionism policy and the huge domestic market as well allow analyzing the importance of international relations and the state support for development of innovations.

In this article it is received the number of conclusions which are reliable according to specification. First, in Russia, as well as in other developing countries, the innovative strategies are connected generally with loan of new technologies. This tendency is not negative as for development of own innovative potential it is required the accumulation of new knowledge and technologies from the developed countries.

The research results outlined in this paper were obtained with financial support from Ministry of Education and Science of the Russian Federation, as part of the execution of the project entitled "Establishment of high-tech production for the manufacture of complex reconfigurable systems of high-precision positioning of objects on the basis of satellite systems of navigation, local networks of laser and microwave beacons and technology MEMS", pursuant to decree of the government of the Russian Federation № 218 issued on April 09, 2010. The researches were carried out in SFedU.

\section{References}

Belman D., Heywood J.S. (1990) The concentration-earnings hypothesis: reconciling individual and industry data in US studies, Oxford Bulletin of Economics and Statistics 52 (3).

Brown, J.S., Duguid, P., (1991) Organizational learning and communities-of-practice: toward a unifyed view of working, learning, and innovation. Organization Science. 2 (1), 40-57.

Buisseret, T., Cameron, H., Georghiou, L. (1995) What difference does it make? Additionality in the public support of R\&D in large firms. International Journal of Technology Management. 10, 587-600.

Cantner, U., Pyka, A. (2001) Classifying technology policy from an evolutionary perspective. Research Policy, 30, 759-775

Djankov, S., Hoekman, B. (2000) Foreign investment and productivity growth in Czech enterprises. World Bank Econ. Rev. 14, 49-64.

Donsimoni M., Geroski P., Jacquemin A. (1984). Concentration indices and market power: two views, Journal of Industrial Economics 32 (4)

Fagerberg, J., Srholec, M. (2008). National innovation systems, capabilities and economic development. Research Policy 37, 14171435.

Fonotov A.G. (2013) Role of the state scientific and technical policy in the increase of innovative activity of the Russian enterprises//Forecasting problems, No. 3 .

Ganichev N. A. (2013) Scenarios of joint innovative development of radio-electronic complex and sector of ICT- services//Forecasting problems. No. 4.

Hoekman, B.K., Maskus, K., Saggi, K. (2005) Transfer of technology to developing countries: unilateral and multilateral policy options. World Development. 33 (10), 1587-1602.

Jaffe, A.B., Trajtenberg, M., (1993) Geographic localization of knowledge spillovers as evidenced by patent citations. Quarterly Journal of Economics.108(3), 577.

Lall, S. (1992) Technological capabilities and industrialization. World Development, 20, 165-186.

Lawrence P., Lorsch J. (1967) Organization and Environment: Managing Differentiation and Integration, Harvard University, Boston, MA.

Malerba, F., Orsenigo, L. (2000) Knowledge, innovative activities and industry evolution. Industrial and Corporate Change. 9, $289-314$.

Malerba, F.F. (1997). Technological regimes and spectral patterns of innovative activities. Industrial and Corporate Change. 6 (1), 83.

Malerbra, F. (2002) Sectoral systems of innovation and production. Research Policy 31 (2), 247-264.

Park, Y.-T. (1999) Technology diffusion policy: a review and classification of policy practices. Technology in Society 21, $275-286$.

Scherer F., Ross D., (1990) Industrial Market Structure and Economic Performance, Houghton Mifflin Company, Boston.

Shevchenko I.K., Razvadovskaya Yu.V. (2013) Structural changes in the Russian Industry 1992-2010. World Applied Science Journal, 28 (6)

Shevchenko I.K., Razvadovskaya Yu.V. (2014) Statistical analysis of Kondratiev water long. Life Science Journal 2014;11(11) 
ISSN 2039-2117 (online) ISSN 2039-9340 (print)
Mediterranean Journal of Social Sciences MCSER Publishing, Rome-Italy
Vol 6 No 3 S4 May 2015 